\title{
Production of $\beta$-Carotene by a Newly Isolated Rhodotorula Glutinis UCP1555 Strain and Cytotoxic Effect Evaluation
}

\author{
Rosileide Fontenele da Silva Andrade ${ }^{1,2}$, Roberto Albuquerque Lima ${ }^{2}$, Daylin Rubio Ribeaux ${ }^{3,4}$, Hélvia Waleska \\ Casulo Araújo ${ }^{4}$, Luciana Oliveira Franco ${ }^{5}$, Adalberto Pessoa-Júnior ${ }^{6}$ and Galba M. Campos-Takaki ${ }^{2}$ \\ 1. National Program Postdoctoral CAPES (PNPD)-Postgraduate in Development of Environmental Processes, Catholic University \\ of Pernambuco, PE, Brazil \\ 2. Nucleus of Research in Environmental Sciences and Biotechnology, Catholic University of Pernambuco, PE, Brazil \\ 3. Center of Biological Sciences, Federal University of Pernambuco, PE, Brazil \\ 4. Chemistry Department, State University of Paraiba, 58429-500, Campina Grande, Paraiba, Brazil \\ 5. Department of Biology, Federal Rural University of Pernambuco, PE, Brazil \\ 6. Department of Pharmacy, University of São Paulo, SP, Brazil
}

\begin{abstract}
Carotenoids have attracted greater attention due to the beneficial role on human health. It is an essential nutrient and has some biological functions such as species-specific coloration, photoprotection, light absorbing, which is an important component because of its role as precursor of vitamin A. In this study was performed the production of $\beta$-Carotene by Rhodotorula glutinis UCP/WFCC 1555 in presence and absence of blue and white using LED (light-emitting diodes) and evaluation of the cytotoxic effect The production was investigated in low cost medium constituted by different concentrations of CG (crude glycerin) and CSL (corn steep liquor) from the CCD (Central Composite Design) and the identification and yield of the $\beta$-Carotene was investigated by chromatographic profile (HPLC). Additionally, the $\beta$-Carotene produced was tested to evaluate its cytotoxic effect in human tumor cells MCF-7 (breast cancer) and HL-60 (promyelocytic leukemia) and healthy cells of macrophages. The results showed that in the medium composed by $6 \%$ glycerin and $0.6 \%$ corn steep liquor, in the absence of light, occurred the maximum production of total carotenoids with values of $160 \mu \mathrm{g} \cdot \mathrm{g}^{-1}$ and these $100.60 \mu \mathrm{g} \cdot \mathrm{g}^{-1}$ correspond to the $\beta$-Carotene that showed ability in inhibit cell growth in several tumor cells such as MCF-7 cells (breast cancer) and HL-60 (promyelocytic leukemia).
\end{abstract}

Key words: $\beta$-Carotene, Rhodotorula glutinis, cytotoxic effect, low-cost medium.

\section{Introduction}

Commercial production of carotenoids from microorganisms competes primarily with the synthetic production by chemical procedures [1,2]. Although the variety of producing microorganisms is large, only a few are industrially interesting, such as yeasts that beyond of produce carotenoids are natural sources of proteins [3].

Corresponding author: Rosileide Fontenele da Silva Andrade, post doctorate CAPES (PNPD), research fields: microbiology and biotechnology.
The synthesis of carotenoids produced by yeasts of the genus Rhodotorula has been investigated indicating high potential for production of pigments [4].

$\beta$-Carotene, a yellow-orange pigment of the carotenoid family, has antioxidant properties [5-8]. This pigment has been employed in pharmaceutical industry, in the production of cosmetics, tanning and food industry [9] and has the protective effect in lowering the risk of cancer [10].

Natural pigments have high importance in the market due to the increase in restrictions of synthetic 
dyes [11]. $\beta$-Carotene had high value in the global market of \$233 million dollars in 2010 and is expected to reach $\$ 309$ million in 2018 with an annual growth rate of $3.6 \%$ [12].

The production of natural carotenoids by biotechnological processes offers advantages compared with synthetics due to the rapid growth of microorganisms versus to higher plants. Thus, the production of by bioprocesses involving microorganisms whose growth speed is relatively high, can ensure a productivity to the process which makes it advantageous $[13,14]$.

Rhodotorula glutinis is strictly aerobic oleaginous yeast that has been used in the production of specific carotenoids as $\beta$-Carotene (precursor of vitamin A), torulene and torularhodin in process fermentative [15].

The cellular toxicity is a complex event and its expression can manifest itself in a broad spectrum of events that ranging from complex metabolic aberrations to the cell death [16]. Thus, the in vitro cytotoxic evaluation allows to determine the safety substances to be used having as aim to ensure that the product is free of undesirable toxic effects [17].

This study aimed to produce $\beta$-Carotene by Rhodotorula glutinis UCP/WFCC 1555, in economic medium employing biotechnological strategies to biomolecule production of high commercial value and preliminarily elucidate the toxic effects of the $\beta$-Carotene of $R$. glutinis in the different cell lines.

\section{Materials and Methods}

\subsection{Microorganism}

Rhodotorula glutinis (UCP/WFCC 1555) was isolated from semi-arid soil of the State of Pernambuco, Brazil, and is maintained at $4{ }^{\circ} \mathrm{C}$ in the medium YMA (Yeast Mold Agar) (0.3\% malt extract, $0.3 \%$ peptone, $1 \%$ glucose and $2 \%$ agar). The isolated was registered in the Culture Collection of Catholic University of Pernambuco and in the WFCC (World Federation for Culture Collections).

\subsection{Substrates}

The substrates used for the production of $\beta$-Carotene were CG (crude glycerin), obtained from the biodiesel production process, and CSL (corn steep liquor), a byproduct from the corn industry which is rich in amino acids.

\subsection{Culture Conditions}

The cultivation of $R$. glutinis was carried out in Erlenmeyer flasks containing $100 \mathrm{~mL}$ of Sabouraud medium (glucose $20 \mathrm{~g}$, peptone meat $3 \mathrm{~g}$ and distilled water $1,000 \mathrm{~mL}$ ) and maintained in orbital shaking at $150 \mathrm{rpm}$ and $28{ }^{\circ} \mathrm{C}$, for $24 \mathrm{~h}$. After this period, $5 \%$ of Sabouraud broth containing $10^{7}$ cells $/ \mathrm{mL}$ was used as pre-inoculum.

\subsection{Influence of Light}

The effect of blue and white LED (light-emitting diodes) was tested on all media of production of total carotenoids in $\beta$-Carotene as attempt to induce the increased production. The control was incubated in the absence of light.

\subsection{Selection of Production Medium}

The production of total carotenoids as $\beta$-Carotene by $R$. glutinis was investigated in different culture media. Initially, it was used the YPD medium (dextrose, peptone and extract yeast) proposed by Martinez et al. [18] and modified by the following composition: $10 \%$ glucose, $0.8 \%$ peptone and $0.3 \%$ yeast extract. This medium was used by Martinez et al. [18] and Dai et al. [19] as standard for growth of $R$. glutinis. Subsequently, replacements of carbon and nitrogen sources were carried out in the modified medium (Table 1).

\subsection{Experimental Design}

A $2^{2}$ CCD (Central Composite Design) with 4 central points and 4 axial points (Table 2) was carried out to evaluate the influence of concentrations of the chemical composition in the media on the production of biomass and total carotenoids. The data of the 
Table 1 Composition of the production media of total carotenoids in $\beta$-Carotene by Rhodotorula glutinis.

\begin{tabular}{llllll}
\hline \multirow{2}{*}{ Media production } & \multicolumn{5}{c}{ Chemical composition (\%) } \\
\cline { 2 - 6 } & $\begin{array}{l}\text { D-Glucose } \\
(\%)\end{array}$ & $\begin{array}{l}\text { Crude glycerin } \\
(\%)\end{array}$ & $\begin{array}{l}\text { Yeast extract } \\
(\%)\end{array}$ & $\begin{array}{l}\text { Corn steep liquor } \\
(\%)\end{array}$ & $\begin{array}{l}\text { Peptone } \\
(\%)\end{array}$ \\
\hline *YPD & 10 & - & 0.8 & - & 0.3 \\
Modified (I) & 10 & - & - & 0.8 & 0.3 \\
Modified (II) & - & 10 & 0.8 & - & 0.3 \\
Modified (III) & - & 10 & - & 0.8 & 0.3 \\
\hline
\end{tabular}

*YPD medium modified.

Table 2 Levels of the $2^{2}$ CCD used to production of biomass and total carotenoids.

\begin{tabular}{llllll}
\hline \multirow{2}{*}{ Factors* } & \multicolumn{5}{c}{ Levels } \\
\cline { 2 - 6 } & -1.41 & -1 & 0 & 1 & -1.41 \\
\hline Crude glycerin (\%) & 4.36 & 6.0 & 10 & 14 & 15.64 \\
Corn steep liquor (\%) & 0.51 & 0.6 & 0.8 & 1.0 & 1.08 \\
\hline
\end{tabular}

*Added peptone $(0.3 \%)$ in all the culture media.

experimental design were analyzed by Statistic software program Windows version 6.0 Statsoft ${ }^{\circledR}$.

\subsection{Determination of Biomass Yield}

Cells were collected from the cultivation media by centrifugation at $10.000 \mathrm{~g}$ and were washed twice with sterile distilled water. The centrifugation process was repeated and the sample was lyophilized. The yield of biomass was calculated by gravimetry and results were expressed in $\mathrm{g} \cdot \mathrm{L}^{-1}$ of dry biomass.

\subsection{Extraction and Partition of Carotenoids}

The total carotenoids were extracted in acetone after cell disruption by maceration method [20]. For this method, $2 \mathrm{~g}$ of biomass of $R$. glutinis were transferred to vessels containing acetone $(50 \mathrm{~mL})$. The extract was filtered with filter paper (Whatman $n^{\circ} 1$ ) and performed the partition in separatory funnel added $40 \mathrm{~mL}$ of petroleum ether and $300 \mathrm{~mL}$ of distilled water.

After phases separation, was discarded the lower aqueous phase. Washing was repeated three times with distilled water to removal of acetone. The ether phase was collected in volumetric flask of $50 \mathrm{~mL}$, covered with aluminum foil, passing the solution through a glass funnel containing $15 \mathrm{~g}$ of anhydrous sodium sulfate to remove residual water. The volume was completed to $25 \mathrm{~mL}$ with petroleum ether [21].

\subsection{Quantification of Total Carotenoids}

The quantification of total carotenoids was carried by spectrophotometry at $450 \mathrm{~nm}\left(\lambda_{\max }\right)$ in the UV-visible, according to protocol described by Rodriguez-Amaya ${ }^{20}$. The extinction coefficient used was relative to the $\beta$-Carotene to petroleum ether $\mathrm{E}_{1 \mathrm{~cm}}^{1 \%}=2,592$. The concentration of total carotenoids was calculated using the formula described by Davies [22]:

$$
C T\left(\frac{\mu g}{100 g}\right)=100\left(\frac{A \times V \times 10^{4}}{E_{1 C M}^{1 \%} \times m}\right)
$$

where, $A=$ absorbance at $450 \mathrm{~nm} ; V=$ final volume of the sample $(\mathrm{mL}) ; m=$ weight of sample $(\mathrm{g})$ and $E^{1 \%}{ }_{1 \mathrm{~cm}}=$ extinction coefficient of the $\beta$-Carotene in petroleum ether.

\subsection{Identification and Quantification of $\beta$-Carotene}

The identification and quantification of $\beta$-Carotene produced by $R$. glutinis were performed in accordance to the chromatographic behavior of the standard beta-carotene (Sigma) by high-performance liquid chromatography-HPLC [23]. This analysis was developed with a column chromatography Sunfire, Waters $\mathrm{C}_{18}, 4.6 \times 250 \mathrm{~mm}$.

The mobile phase was composed mobile phase consisting of methanol: ethyl acetate: acetonitrile (50:40:10), with flow $0.6 \mathrm{~mL} \cdot \mathrm{min}^{-1}$, run time 7.5 
minutes and $30{ }^{\circ} \mathrm{C}$ oven temperature. Detection was performed using chromatograms read in wavelength of $450 \mathrm{~nm}$. The solvents used were chromatographic grade and all the samples were filtered through a polyethylene membrane with pore $0.22 \mu \mathrm{m}$.

The identification of $\beta$-Carotene in the sample was performed by comparing the retention time obtained with the standard $\beta$-Carotene and the quantification was performed after construction of the standard curve with six different concentrations $(0.05-0.5 \mu \mathrm{g} / \mathrm{mL})$ using the peak area for the calculation of the concentration [20].

\subsection{Evaluation of the Cytotoxic Activity of $\beta$-Carotene}

The cytotoxic activity was performed using the reduction method

MTT ([3-(4,5-Dimethylthiazol-2-yl)-2,5-Diphenyltetrazoliu m Bromide] [24, 25]. The J744.A1 cells (murine macrophage) were maintained in DMEM culture medium and the human tumor cell HL-60 (human promyelocytic leukemia) and MCF-7 (breast cancer) were maintained in RPMI culture medium. The medium was supplemented with $10 \%$ fetal bovine serum and $1 \%$ antibiotic solution (penicillin and streptomycin). The cells were maintained in incubator at $37{ }^{\circ} \mathrm{C}$ in atmosphere enriched with $5 \% \mathrm{CO}_{2}$. The MCF-7 $\left(10^{5}\right.$ cells $\left./ \mathrm{mL}\right)$, HL-60 $\left(3 \times 10^{5}\right.$ cells $\left./ \mathrm{mL}\right)$ and J744.A1 $\left(1.75 \times 10^{5}\right.$ cells $\left./ \mathrm{mL}\right)$ cells were plated in 96 well plates and incubated for $24 \mathrm{~h}$. Subsequently, the $\beta$-Carotene extract produced by $R$. glutinis was dissolved in DMSO (1\%) and added to the wells in final concentration of $25 \mu \mathrm{g} / \mathrm{mL}$.

The $\beta$-Carotene (SIGMA) at a concentration of 25 $\mu \mathrm{g}$ was used as standard. After $72 \mathrm{~h}$ of re-incubation was added $25 \mu \mathrm{L}$ of MTT $(5 \mathrm{mg} / \mathrm{mL})$ and after of $3 \mathrm{~h}$ incubation, the cultivation medium with MTT was aspirated and $100 \mu \mathrm{L}$ DMSO was added to each well. The absorbance was measured in reader of microplate at a wavelength of $560 \mathrm{~nm}$. The experiments were analyzed with the program Graph Pad Prism 5.0. Each sample was tested in triplicate. A scale of intensity was used to evaluate the cytotoxic effect of the tested samples of $\beta$-Carotene: absence activity ( 1 to $20 \%$ inhibition), with little activity (cell growth inhibition varying from 20 to $50 \%$ ), with moderate activity (cell growth inhibition varying from 50 to $70 \%$ ) and much activity (growth inhibition varying from 70 to $100 \%$ ) [26].

\section{Results and Discussion}

3.1 Production of Total Carotenoid by Rhodotorula Glutinis under Influence of Blue and White LEDs (Light-Emitting Diodes) and in the Absence of Light

R. glutinis is grown in absence of light (control) in YPD medium containing glucose as sole carbon source and produced $123.12 \mu \mathrm{g} \cdot \mathrm{g}^{-1}$ of total carotenoids. However, the higher production of the total carotenoids (127.86 $\mu \mathrm{g} \cdot \mathrm{g}^{-1}$ ) occurred in modified medium (III) consists of crude glycerin (10\%), corn steep liquor $(0.8 \%)$ and peptone $(0.3 \%)$, after $96 \mathrm{~h}$ of cultivation under the influence of blue LED (Fig. 1). Lababpour et al. [27] and Tatsch [28] affirmed that the light can be used as a factor influencing the production of carotenoids.

\subsection{Effect of the Concentrations of Culture Medium Components}

Based on the initial results of higher productivity in total carotenoids induced by blue LED (light-emitting diodes), the modified medium (III) was used for further investigations.



Fig. 1 Total carotenoid produced by Rhodotorula glutinis in YPD media and modified media I, II and III. 
A $2^{2}$ CCD was carried out to analyze the effect of the concentrations of culture medium components on the biomass production $\left(\mathrm{g} \cdot \mathrm{L}^{-1}\right)$ and total carotenoids $\left(\mu \mathrm{g} \cdot \mathrm{g}^{-1}\right.$ of dry biomass) as response variables.

The results showed that the condition 1 of the CCD allowed the increase of the production of total carotenoids $\left(156.65 \mu \mathrm{g} \cdot \mathrm{g}^{-1}\right)$ induced by blue LED (Table 3). In this condition, the culture medium was composed by minimal levels of CG $(6 \%)$ and CSL $(0.6 \%)$.

The condition 8 of the CCD resulted in higher biomass yield $\left(4.98 \mathrm{~g} \cdot \mathrm{L}^{-1}\right)$, in medium with high level of CSL (1.082\%) and intermediate levels of CG (10\%). Peptone $(0.3 \%)$ was constant in all the conditions of CCD (Table 3).

Total carotenoids, thereby as relative amounts of pigment, vary according to the species of Rhodotorula and different conditions of the medium [29]. In this context, the total carotenoid content produced in this study were higher than those produced by $R$. lactosa $\left(105.8 \mu \mathrm{g} \cdot \mathrm{g}^{-1}\right)$ and R. minuta $\left(103.7 \mu \mathrm{g} \cdot \mathrm{g}^{-1}\right)$ in medium containing glucose as only carbon source [30] and similar to the results obtained by Squina and Mercadante [31] that resulted in $123.5 \mu \mathrm{g} \cdot \mathrm{g}^{-1}$ of total carotenoids by Rhodotorula rubra.

The analysis of variance (ANOVA) of the data from $2^{2} \mathrm{CCD}$ determined the independent factors that had the greatest influence on the production of carotenoids. Statistical analysis shows that small values of $p$. associated to the higher values of $F$ validate statistical model effects once and demonstrate that effects were higher than the standard error (Table 4).

The evaluation of glycerin concentrations and corn steep liquor on the L.T (linear term) and Q.T (quadratic term), thereby as their interactions are represented by diagram with $95 \%$ of confidence (Fig. 2).

Table 3 Results of the CCD for biomass production and total carotenoids by Rhodotorula glutinis induced by blue LED.

\begin{tabular}{lllll}
\hline Conditions & Glycerin $(\%)$ & Corn steep liquor $(\%)$ & Total carotenoids $\left(\mu \mathrm{g} \cdot \mathrm{g}^{-1}\right)$ & Biomass $\left(\mathrm{g} \cdot \mathrm{L}^{-1}\right)$ \\
\hline 1 & 6.00 & 0.60 & 156.65 & 4.20 \\
2 & 6.00 & 1.00 & 87.63 & 2.95 \\
3 & 14.00 & 0.60 & 50.01 & 3.88 \\
4 & 14.00 & 1.00 & 120.62 & 3.66 \\
5 & 4.36 & 0.80 & 100.75 & 3.01 \\
6 & 15.64 & 0.80 & 62.38 & 2.97 \\
7 & 10.00 & 0.51 & 111.23 & 3.61 \\
8 & 10.00 & 1.08 & 128.06 & 4.98 \\
9 & 10.00 & 0.80 & 124.32 & 4.00 \\
10 & 10.00 & 0.80 & 127.10 & 3.94 \\
11 & 10.00 & 0.80 & 123.86 & 3.61 \\
12 & 10.00 & 0.80 & 123.41 & 3.20 \\
\hline
\end{tabular}

*Added peptone $(0.3 \%)$ in all conditions.

Table 4 ANOVA (analysis of variance) of the significant factors.

\begin{tabular}{llllccc}
\hline Variable response & $\begin{array}{l}\text { Independent } \\
\text { variables }\end{array}$ & Sum of squares & $\begin{array}{l}\text { Degree of } \\
\text { freedom }\end{array}$ & $\begin{array}{l}\text { Mean of the } \\
\text { squares }\end{array}$ & F-Valor & $\begin{array}{l}\text { Confidence } \\
\text { level (p) }\end{array}$ \\
\hline & Glycerin $_{(\mathrm{L} . \mathrm{T})}$ & $1,065.42$ & 1 & $1,065.42$ & 604.82 & 0.000147 \\
& Glycerin $_{(\mathrm{Q} . \mathrm{T})}$ & $1,902.88$ & 1 & $1,902.88$ & $1,080.2$ & 0.000062 \\
& Corn steep liquor $_{(\mathrm{L} . \mathrm{T})}$ & 114.87 & 1 & 114.877 & 65.214 & 0.003967 \\
T.C (Total & Con steep liquor $(\mathrm{Q} . \mathrm{T})$ & 25.87 & 1 & 25.873 & 14.688 & 0.0311309 \\
carotenoids) & Assoc. Glic.(L.T)/Milhoc.(L.T) & $2,585.72$ & 1 & $2,585.72$ & $1,467.8$ & 0.0000039 \\
& Adjustment of error & 11.32 & 3 & 3.775 & 2.143 & 0.273716 \\
& pure error & 5.28 & 3 & 1.762 & & \\
& Total sum of squares & $5,699.30$ & 11 & & & \\
\hline
\end{tabular}






Fig. 2 Pareto diagram for studies of the effects of the independent variables glycerin and corn steep liquor on the production of carotenoids by Rhodotorula glutinis.

According to Pareto diagram the association between glycerin and corn steep liquor in linear contributions presented greater influence in the production of total carotenoids. This indicated the reach of optimal concentrations to the culture medium under on conditions tested in this work.

Moreover, all independent variables were significantly represented with values above the line $\mathrm{p}$.

\subsection{Identification of the $\beta$-Carotene by Rhodotorula} Glutinis by HPLC

The identification and yield of the production of $\beta$-Carotene was investigated by chromatographic profile (HPLC) using as standard the $\beta$-Carotene (Sigma) (Fig. 3A). Fig. 3B shows the chromatographic profile (HPLC) of the $\beta$-Carotene produced by $R$. glutinis in medium consisting of $6 \%$, glycerin, $0.6 \%$ CSL and $0.3 \%$ peptone in presence of blue light and the Fig. $3 \mathrm{C}$ shows the identification of $\beta$-Carotene produced by $R$. glutinis in the same medium in the absence of blue light.

The $\beta$-Carotene standard was identified by RT $($ retention time $)=8.850 \mathrm{~min}$. Similar results were found in the $\beta$-Carotene extracted from biomass of $R$. glutinis $(\mathrm{RT}=8.851 \mathrm{~min}$.) produced in medium consisting of $6 \%$ glycerin, $0.6 \% \mathrm{CSL}$ and $0.3 \%$ peptone in presence of blue light.

In the same medium in the absence of blue light the retention time found was similar to the standard $(\mathrm{RT}=$ $8.844 \mathrm{~min}$ ), confirming the presence of $\beta$-Carotene in sample.

The yield of $\beta$-Carotene in medium containing blue light was $82.02 \mu \mathrm{g} / \mathrm{g}$ and in medium with absence of blue light was $100.60 \mu \mathrm{g} / \mathrm{g}$ of $\beta$-Carotene. These results show that the higher yields of $\beta$-Carotene were obtained after removal of blue light of the production process ensuring a low-cost production. 



Fig. 3 Chromatogram of $\beta$-Carotene produced by Rhodotorula glutinis: (A) Standard $\beta$-Carotene (Sigma); (B) $\beta$-Carotene produced in medium consisting of $6 \%$ glycerin, $0.6 \%$ corn steep liquor and $0.3 \%$ peptone in blue light and (C) $\beta$-Carotene produced in medium consisting of $6 \%$ glycerin and $0.6 \%$ corn steep liquor and $0.3 \%$ peptone, in the absence of blue light.

The production of $\beta$-Carotene by $R$. glutinis in this study was similar to that obtained by Neto [32], which worked with a strain of $R$. glutinis that was able of $\beta$-Carotene produce in medium containing cashew juice as carbon source. The production ranged from 5.0 to $120 \mathrm{mg} / \mathrm{g}$ of $\beta$-Carotene.

\section{4 $\beta$-Carotene Cytotoxicity}

The cytotoxic activity of carotenoids on many cancer cell lines has been attributed to their prooxidant activity through the generation of ROS [33]. In this context, in this work the $\beta$-Carotene produced by $R$. glutinis in medium consisting of $6 \%$ glycerin and
$0.6 \% \mathrm{CSL}$ and $0.3 \%$ peptone, was tested to evaluate its cytotoxic activity in human tumor cells MCF-7 (breast cancer) and HL-60 (promyelocytic leukemia) and healthy cells of macrophages (J774.A1) (Table 5).

The results demonstrated that the sample of $\beta$-Carotene of $R$. glutinis inhibited cell growth of MCF-7 (cells of breast cancer) and J774.A1 (cells of macrophages) in $27.93 \%$ and $21.72 \%$, respectively, resulting in low cytotoxic activity. However, the cytotoxic activity of $\beta$-Carotene of $R$. glutinis was moderate against the HL-60 cell (promyelocytic leukemia). $\beta$-Carotene has the potential to inhibit cell growth of various tumor cells such as melanoma [17], 
Table 5 Evaluation of the cytotoxic effect of $\beta$-Carotene produced by Rhodotorula glutinis.

\begin{tabular}{llllllll}
\hline \multirow{2}{*}{ Test product } & \multicolumn{7}{c}{ \% Inhibition of cell growth } \\
\cline { 2 - 7 } & MCF-7 & S.E & HL-60 & S.E & J774.A1 & S.E \\
\hline$\beta$-Carotene sample & 27.93 & 1.42 & 61.17 & 0.00 & 21.72 & 1.43 \\
$\beta$-Carotene standard & 25.49 & 1.75 & 35.86 & 0.38 & 23.53 & 2.34 \\
\hline
\end{tabular}

*Standard error-S.E

prostate [3], colon [11], lung, breast and cancer of the oral mucosa [2]. In this context, the $\beta$-Carotene produced by $R$. glutinis under the conditions studied in this work demonstrated to be a potent carotenoid effective in inhibiting the cellular growth of tumor cells such as MCF-7 cells (breast cancer) and HL-60 (promyelocytic leukemia).

\section{Acknowledgments}

This work was financially supported by CAPES (Coordenação de Aperfeiçoamento de Pessoal de Nível Superior), CETENE (Centro de Tecnologias Estratégicas do Nordeste) and Corn Products (Cabo de Santo Agostinho-PE, Brazil) kindly provided the substrate of corn steep liquor. The authors are also grateful to the NPCIAMB (Nucleus of Research in Environmental Sciences and Biotechnology), Catholic University of Pernambuco (Recife-PE, Brazil) for the use of its laboratories.

\section{References}

[1] Hernández-Almanza, A., Montanez, J. C., Aguiar-Gonzáles, M. A., Martínez-Ávila, C., Rodríguez-Herrera, R., and Aguilar, C. N. 2013. "Rhodotorula Glutinis as Source of Pigments and Metabolites for Food Industry." Food Biosc. 5: 64-72.

[2] Kanzi, H. M., Nasr, N. F., El-Shazl, H. A. M., and Barakat, O. S. 2015. "Optimization of Carotenoids Production by Yeast Strains of Rhodotorula Using Salted Cheese Whey." Int. J. Curr. Microbiol. App. Sci. 4: 456-69.

[3] Valduga, E., Tatsch, P. O., Tiggemann, L., Treichel, H., Toniazzo, G., Zeni, J., Di Luccio, M., and Fúrigo Júnior, A. 2009. "Produção de Carotenoides: Microrganismos Como Fonte de Pigmentos Naturais." Quim. Nova 32: 2429-36.

[4] Marova, I., Andrea, H., Sinisa, P., Dvorakova, T., and Breierova, E. 2012. "Production of Enriched Biomass by
Red Yeasts of Sporobolomyces sp. Grown on Waste Substrates." J. Microbiol. Biotechnol. 4: 534-51.

[5] López-Nieto, M. J., Costa, J., Peiro, E., Méndez, E., Rodríguez-Sáiz, M., Fuente, J. L., Cabri, W., and Barredo, J. L. 2004. "Biotechnological Lycopene Production by Mated Fermentation of Blakeslea Trispora." Appl. Microbiol. Biotechnol. 66: 153-9.

[6] Soni, M., Thurmond, T. S., and Miller, E. R. 2010. "Safety of Vitamins and Minerals: Controversies and Perspective." Toxicol. Sci. 118: 348-55.

[7] Malisorn, C., and Suntornsuk, W. 2009. "Improved $\beta$-Carotene Production of Rhodotorula Glutinis in Fermented Radish Brine by Continuous Cultivation." Biochem. Engin. J. 43: 27-32.

[8] Sommerburg, O., De Spirt, S., Mattern, A., Joachim, C., Langhans, C. D., Nesaretnam, K., Siems, W., Stahl, W., and Mall, M. A. 2015. "Supplementation with Red Palm Oil Increases $\beta$-Carotene and Vitamin a Blood Levels in Patients with Cystic Fibrosis." Mediat. Inflammat. 1: 1-7.

[9] El-Banna, A. A., El-Razek, A., and El-Mahdy, A. R. 2012. "Some Factors Affecting the Production of Carotenoids by Rhodotorula Glutinis var. Glutinis." Food and Nutrit. Scienc. 3: 64-71.

[10] Sacha, T., Zawada, M., Hartwich, J., Lach, Z., Polus, A., Szostek, M., Zdziyowska, E., Libura, M., et al. 2005. "The Effect of $\beta$-carotene and Its Derivatives on Cytotoxicity, Differentiation, Proliferative Potential and Apoptosis on the Three Human Acute Leukemia Cell Lines: U-937, HL-60 and TF-1." Biochim. Bioph. Act. 2: 206-14.

[11] Três, M., FrancheschI, E., Borges, G. R., Dariva, C., Corazza, F. C., Oliveira, J. V., and Corazza, M. L. 2007. "Influência da Temperatura na Solubilidade de $\beta$-Caroteno em Solventes Orgânicos à Pressão Ambiente." Rev. Ciênc.Tecnol. Aliment. 27: 737-43.

[12] Mata-Gómez, L. C., Montañez, J. C., Méndez-Zavala, A., and Aguilar, C. N. 2014. "Biotechnological Production of Carotenoids by Yeasts: An Overview." Microb. Cell Fact. 13: 1-11.

[13] Maldonade, I. R., Rodriguez-Amaya, D. B., and Scamparini, A. R. P. 2012. "Statistical Optimisation of Cell Growth and Carotenoid Production." Rhodotorula Mucilaginosa. Braz. J. Microbiol. 43: 109-15.

[14] Tkáčová, J., Furdíková, K., and Klempová, T. 2015. 


\section{Strain and Cytotoxic Effect Evaluation}

"Screening of Carotenoid-Producing Rhodotorula Strains Isolated from Natural Sources." Acta Chim. Slovaca 8: 34-8.

[15] Moliné, M, Libkind, D., and Van Broock, M. 2012. "Production of Torularhodin, Torulene, and $\beta$-Carotene by Rhodotorula Yeasts." Methods Mol. Biol. 898: 275-83.

[16] Vian, L., Vincent, J., Maurin, J., Fabre, I., Giroux, J., and Cano, J. P. 1995. "Comparison of Three in Vitro Cytotoxicity Assays for Estimating Surfactant Ocular Irritation." Toxicol. In Vitro. 2: 185-90.

[17] Chiba, K., Makito, I., Ohuch, J., Kasai, Y., Kakishima, H., Tsukumo, K., Uchiyama, T., Miyai, E., et al. 1999. "Interlaboratory Validation of the in Vitro Eye Irritation Test for Cosmetic Ingredient: Evaluation of Citotoxicity Test on HeLa Cells". Toxicol. in vitro 13: 189-98.

[18] Martínez, C., Gertosio, C., Labbe, A., Pérez, R., and Ganga, M. A. 2006. "Production of Rhodotorula Glutinis: A Yeast that Secretes $\alpha$-Larabinofuranosidase". Electron. J. Biotechnol. 9: 407-13.

[19] Dai, C., Tao, J., Xie, F., Dai, Y. J., and Zhao, M. 2007. "Biodiesel Generation from Oleaginous Yeast Rhodotorula Glutinis with Xylose Assimilating Capacity." Afric. J. Biotechnol. 6: 2130-4.

[20] Scutte, H., and Kula, M. R. 1990. "Pilot Process-Scale and Techniques for Cell Disruption." Biotechnol. Appl. Biochem. 12: 599-620.

[21] Rodriguez-Amaya, D. B. 1999. A Guide to Carotenoids Analysis. International Life Sciences. Institute Press, 64.

[22] Davies, B. H. 1976. Carotenoids in Chemistry and Biochemistry of Plant Pigments. edited by Goodwin, T. W. New York: Academic Press, 38-165.

[23] Pinheiro-Santana, H. M., Stringheta, P. C., and Brandão, S. C. C. 1998. "Carotenoid Retention and Vitamin A Value in Carrot (Daucus carota L.) Prepared by Food Service." Food Chem. 61: 145-51.

[24] Mosmann, T. 1983. "Rapid Colorimetric Assay for Cellular Growth and Survival: Application to Proliferation and Cytotoxicity Assays." J. Immunol.
Methods 65: 55-63.

[25] Alley, M. C., Scudiero, D. A., Monks, A., Miriam, J., Czerwinski, M. J., Fine, D. L., Abbott, B. J., Mayo, J. G., et al. 1988. "Feasibility of Drug Screening with Panels of Human Tumor Cell Lines Using a Microculture Tetrazolium Assay." Canc. Research 48: 589-60.

[26] Fouche, G., Cragg, G. M., Pillay, P., Kolesnikova, N., Maharaj, V. J., and Senabe, J. 2008. "In Vitro Anticancer Screening of South African Plants." J. Ethnopharmacol. 3: 455-61.

[27] Lababpour, A., Shimahar, K., Hada, K., Kyoui, Y., Katsuda, T., and Katoh, S. 2005. "Fed-batch Culture under Illumination within Blue LEDs (Light Emitting Diodes) for Astaxanthin Production by Haematococcus pluvialis.” J. Biosc. Bioeng. 100: 339-42.

[28] Tatsch, P. O. 2008. Produção de Carotenóides em meio sintético por Sporidiobolus salmonicolor CBS2636 em biorreator. 94f. Dissertação (mestrado)-Universidade Regional Integrada do Alto Uruguai e das Missões. Curso de mestrado em Engenharia de Alimentos.

[29] Squina, F. M., Yamashita, F., Pereira, J. L., and Marcadante, A. Z. 2002. "Production of Carotenoids by Rhodotorula Rubra and R. Glutinis in Culture Medium Supplemented with Sugar Cane Juice.” Food Biotechnol. 16: 227-35.

[30] Perrier, V., Dubreucq, E., and Galzy, P. 1995. "Fatty Acid and Carotenoid Composition of Rhodotorula Strains." Arch. Microbiol. 164: 173-9.

[31] Squina, F. M., and Mercadante, A. Z. 2003. "Análise por CLAE, de Carotenóides de Cinco Linhagens de Rhodotorula." Rev. Bras. Ciênc. Farmac. 39: 309-18.

[32] Neto, H. C. G. 2010. Monografia: Produção Microbiológica de Betacaroteno Usando Suco de Caju Como Fonte de Carbono, 31.

[33] Agarwal, S., Sharma, V., Kaul, T., Abdin, M. Z., and Singh, S. 2014. "Cytotoxic Effect of Carotenoid Phytonutrient Lycopene on P. Falciparum Infected Erythrocytes." Molec. Bioch. Parasit. 197: 15-20. 